'They'll Never Understand Why I'm Here': British Marxism and the Irish Revolution, 1916-1923

The Irish Revolution of 1916-23 lies perhaps second in importance only to the Great Famine as an event-or related series of events-which would not so much shape as transform the course of modern Irish history thereafter. Beginning with the Easter Rising in 1916 and culminating in the Irish Civil War of 1922-23, it was a revolution that was characterised by an explosive republican challenge to British rule and astonishing levels of labour militancy, but one, ultimately, that resulted in the creation of two conservative Irish states and the thwarting of Irish republican and socialist ambitions. Not surprisingly, it is a period that has long fascinated and divided historians, but which is also currently subject to unprecedented popular interest, as the so called 'Decade of Commemoration' moves into full swing.

The relationship between British social democracy and the Irish Revolution has been examined. ${ }^{1}$ But an area that remains relatively under-researched has been the connection between British revolutionary socialists and Irish revolutionaries. Although often referred to in passing in examinations of the Irish Revolution, ${ }^{2}$ or the British socialist movement, ${ }^{3}$ it has rarely been the main focus of study itself. The main exceptions here are David Reed's 1984 work, Ireland: the Key to the British Revolution and Geoffrey Bell's recent Hesitant Comrades: The British Labour Movement and the Irish Revolution. Reed devoted a chapter to the 1916-1921 period. Here, a contrast was made between the 'social democratic wing'

\footnotetext{
${ }^{1}$ See Ivan Gibbons, British Labour Party and the Establishment of the Irish Free State (London: 2015)

${ }^{2}$ See, for example, CD Greaves, The Life and Times of James Connolly (London: 1961); Emmet O'Connor, Reds and the Green, Ireland, Russia and the Communist Internationals, 1919-1943, (Dublin: 2004)

${ }^{3}$ See, for example, Raymond Challinor, Origins of British Bolshevism, (London: 1977); Neil Redfern, Class or Nation? Communists, Imperialism and Two World Wars (London: 2005)
} 
of the labour movement, which included the ILP and Labour Party, who, in Reed's view, 'did not support the struggle of the Irish people for a democratic republic' and the revolutionaries in organisations such as the Workers Socialist Federation (WSF) and, later, the Communist Party of Great Britain, (CPGB) who 'consistently' did support it, but were too weak to affect the outcome. Although criticised for focusing too much on the question of affiliation to the Labour Party during this period, the CPGB was singled out for praise by Reed for recognising the imperialist nature of the Treaty settlement in December 1921 and opposing it. 4

Bell's excellent monograph began life as a PhD and also covers the period up to the Treaty in December 1921. The focus here is more on the Labour Party and trade unions, as well as the ILP. But the Marxist organisations are not ignored, and there is occasional, partial coverage of their input, which, like Reed's account, is based mainly on a review of their publications. Bell is also critical of the ideological shortcomings of the mainstream British labour movement organisations, and their failure to support or involve themselves in the campaign for full republican independence. The revolutionary socialist organisations are also subjected to criticism on these grounds, but in a milder fashion. And like Reed, Bell concludes his investigation by praising the CPGB, for its analysis of the Treaty, seeing it as their 'finest theoretic hour'. ${ }^{5}$

Perhaps what remains under-represented in the literature is an analysis that focuses more squarely and directly on the Marxist organisations; one that examines not only their

\footnotetext{
${ }^{4}$ David Reed, Ireland: the Key to the British Revolution, (London: 1984), pp74-78.

${ }^{5}$ Geoffrey Bell, Hesitant Comrades: The British Labour Movement and the Irish Revolution, (London: 2016), p213
} 
pronouncements and their publications, but also some of their actions; one that looks at the inter-play between British and Irish revolutionaries; and, crucially, one that does not stop in December 1921, but which continues into the Civil War period. This paper is a contribution in this direction. It is intended to examine the input of British-based Marxist revolutionary organisations into the Irish Revolution, up to and including the Civil War. The focus will be placed on the Socialist Labour Party, (SLP) the British Socialist Party (BSP) and the CPGB which were the main Marxist organisations in British politics at that point.

\section{Roots and context}

Ireland had long been of interest to radical political activists in Britain. From the example of the famous Leveller, William Walwyn, ${ }^{6}$ to the Scottish radical, Thomas Muir, who made connections with the United Irishmen in $1793,{ }^{7}$ the long struggle of the Irish for selfdetermination and freedom was viewed as important. As political exiles in $19^{\text {th }}$ century London, both Marx and Engels devoted time to analysis and political activism in support of Irish revolutionaries. Their view on the sequencing of revolutionary change in Ireland and Britain altered after the Great Famine but throughout their long years of political activism, the guiding principle of their work was consistent and two-fold: firstly, the support they offered for Irish independence was based not merely on sympathy, and a desire to assist the liberation of the 'earliest English colony' from the 'iron hand' of a 'parasitic' oppressor ${ }^{8}$ but a deep analysis of the economic relationship between the two countries. From the $1860 \mathrm{~s}$ onwards, Marx increasingly viewed Ireland as the key to revolution in Britain, arguing that the destruction of the power of 'landed English oligarchy' in Ireland would erode its strength

\footnotetext{
${ }^{6}$ Christopher Hill, The World Turned Upside Down: Radical Ideas During the English Revolution, (London: 1991), p336

${ }^{7}$ AW Smith, 'Irish Rebels and English Radicals, 1798-1820', Past and Present, 7, 1, (1955), p79.

${ }^{8}$ Engels to Marx, 23 May 1856, in Marx/Engels Ireland and the Irish Question, (Moscow: 1986), p84.
} 
in Britain, and was the 'prime condition' of British working class emancipation. ${ }^{9}$ Secondly, both recognised the autonomy of Irish organisations and opposed attempts by British socialists to control them. The best example of this was Engels' excoriation of Hales, a leading English member of the International, who had objected to separate Irish branches of the organisation in Britain, arguing that it was at odds with the 'fundamental principle' of the association, 'which was to destroy all semblance of the nationalist doctrine and remove all barriers that separated man from man'. For Engels, asking the Irish, a 'conquered people' to forget their nationality and 'submit to the conquerors' was 'not internationalism, but simply prating submission'. ${ }^{10}$

These principles of identifying a material basis for support of Irish independence and full respect for the independence of Irish organisations were something of a legacy that Marx and Engels bequeathed to British socialists, but, as will be discussed below, would not always guide their actions during the revolutionary era, an era that would open with the Easter Rising of 1916.

\section{James Connolly, the Easter Rising and the British Socialist movement}

It is appropriate that a discussion on the relationship between the Irish and British socialists during the Irish Revolution should begin with James Connolly. Born in Edinburgh in 1868 to Irish immigrant parents, Connolly was recruited to the socialist movement by John Leslie, secretary of the Edinburgh-based Scottish Socialist Federation. Leslie, twelve years older than Connolly, and also the child of Irish immigrants, had himself a long standing interest in

\footnotetext{
${ }_{9}^{9}$ Marx to Ludwig Kugelmann, 29 November 1869, in Marx/Engels, Ireland and Irish Question, (Moscow: 1986) pp378-379.

${ }^{10}$ Council meeting, 14 May 1872, Marx/Engels, Ireland, pp504-511
} 
Ireland. In 1894, he published a series of articles in the Social Democratic Federation (SDF) newspaper, Justice, where he sketched out a materialist analysis of Irish history under the Union. ${ }^{11}$ Connolly's own classic challenge to bourgeois nationalist historiography, Labour in Irish History, was clearly inspired to some degree by this work, and it was Leslie who also encouraged the younger man to move to Dublin in 1896, to take up the position of organiser for the Dublin Socialist Society, later renamed the Irish Socialist Republican Party (ISRP). Connolly's political focus from that point onwards was riveted on Ireland. He wrote prolifically on the relationship between Irish nationalism and socialism, arguing that only through the destruction of British capitalist-imperialism in Ireland could genuine independence be achieved. Only the 'incorruptible' Irish working class could lead this struggle, as the middle-classes were bound to British capitalism by a 'thousand economic strings'. ${ }^{12}$ Connolly also maintained regular contact with British socialists in the form of letters, articles, speaking tours and even the establishment of some British-based ISRP branches. It would be during one of these tours that Connolly would assist his Scottish comrades who had split from the SDF, acting for a short spell as the first chairman of their new organisation, the SLP. ${ }^{13}$

From August 1914 onwards, James Connolly was of course committed to the idea of a Rising against British rule in Ireland. He believed that a decaying British imperialism could stave off its decline by defeating Germany and that if this happened, Ireland might be held in its grip and repressed for another generation, with the hard-fought rights and liberties of Irish workers being destroyed in the process. ${ }^{14}$ It was as a result of this particular

\footnotetext{
${ }^{11}$ Republished as John Leslie, The Irish Question 1894, (Cork Workers' Club: 1976)

12 James Connolly, Labour in Irish History, (Dublin: 1983), pXXXii.

${ }^{13}$ Donal Nevin, James Connolly: a Full Life, (Dublin: 2005), p205.

${ }^{14}$ For more on Connolly's views here see the Irish Worker, 29 August 1914; Workers' Republic, 20 November 1915; Workers' Republic, 9 October 1915, 8 April 1916.
} 
perspective that Connolly became convinced of the need to strike while the opportunity afforded by the war was still present. Both Kendall and Challinor indicate that his former associates in the SLP were either involved in or knew about the 'preliminaries' for the Easter Rising, ${ }^{15}$ but there is no evidence that this was the case. Indeed, given the secretive nature of the planning and the somewhat negative public attitude the SLP would later display about the Rising, it is almost certainly the case that they were not.

Connolly had maintained contact with the SLP, despite the strain in relations caused by his public rupture with US SLP leader and theoretician, Daniel de Leon. He had a regular correspondence with J.C. Matheson and, in later years, Arthur McManus, who by the outbreak of the First World War had become a leading figure within the SLP and editor of the party newspaper, the Socialist. In 1915, McManus had published Connolly's Irish Worker, following its suppression in Ireland, working 'night and day to get the paper printed and personally escorting it to Dublin, with the journal wrapped up in a parcel marked 'glass'. ${ }^{16}$ The Belfast-born McManus was, like all of the SLP leaders, hugely influenced by James Connolly, but this was probably the full extent to which he and the party played in assisting the Irish socialist leader during this period.

Clearly, then, the SLP had close links with James Connolly, which had been sustained throughout many years of activity. But in the aftermath of the Rising, the party adopted a policy of silence. No support was offered to the republicans and no criticism was made of the government. There was no attempt to understand or analyse the reasons for Connolly's

\footnotetext{
${ }^{15}$ Walter Kendall, The Revolutionary Movement in Britain, 1900-1921, (London: 1969), p373; and Raymond Challinor, Origins, p158

${ }^{16}$ Challinor, Origins, p127.
} 
participation. At first glance, this seems odd, especially when it is considered that McManus did have some insight into Connolly's thoughts and actions. In November 1915 and January 1916, Connolly had written to the SLP leader, commenting on how the 'high handedness' and 'ruthlessness' of the British state was pushing Ireland to the point of 'social revolution'. ${ }^{17}$ Most remarkably of all, there was no obituary of Connolly in the pages of the Socialist - in fact, no mention of his execution at all in the pages of the party he had helped to establish. And in the period following the Rising, the SLP would continue to say very little about Ireland. In the June edition of the Socialist, the party contented itself with the rather banal observation: 'leaving the merits or demerits of the revolt aside, it will now be realised that armies are the force used by capitalists to maintain their undisputed sway. ${ }^{18}$

Harry McShane, then a member of the BSP in Glasgow, recollected in his memoirs that the SLP was 'completely split' by the Rising, and that while their 'best comrades' supported it, many others within the party who continued to hold to a syndicalist perspective did not 'because it was not based on industry.' ${ }^{19}$ Certainly, the SLP was heavily influenced by industrial unionism and was yet to fully shake off its sectarian approach to other socialist organisations who did not subscribe to this model of revolutionary change. But the puzzle continues over why an apparently divided party could be so united in its silence on such an issue-especially if some of its leaders were in favour of it. The only conclusion to be drawn is that the SLP remained quiet on the Rising, because no section of the party either understood or supported it. It possibly appeared to them as a purely nationalist rebellion and so far removed from what they regarded as 'normal' socialist political activity, that it

\footnotetext{
${ }^{17}$ One of these two letters was published in the Socialist, 17 April 1919. The other letter was seized by police, following McManus' arrest in 1916.

${ }^{18}$ The Socialist, June 1916

${ }^{19}$ Harry McShane, No Mean Fighter, (London: 1978), pp82-83
} 
could not be supported. But at the same time, the party clearly did not want to publicly condemn the executed Connolly, hence the policy of silence.

This attitude of the SLP highlights some of the theoretical problems nationalism had posed for Marxists at this point. Although Marx and Engels had written a substantial amount about Ireland and supported Irish independence, no general principles had been established on the relationship between nationalism and socialism within or without colonial states. By the time of the Easter Rising, some important developments had occurred. In 1903, the Russian Social Democratic and Labour Party had inserted a clause in its programme which granted a right of self-determination to those oppressed nationalities locked within the Tsarist state. However, this measure had provoked debates between some of the Bolsheviks who defended the clause, and those Polish Marxists who opposed it. The most significant of these was the debate involving Lenin and Rosa Luxemburg, which fully opened up several years later. Lenin considered the clause to be a measure that would weaken the power of reactionary 'Great Russian' chauvinism and assist the building of 'an alliance of all proletarians of all nations on an equal footing'. ${ }^{20}$ Interestingly, he drew on Marx and Engels' writings on Ireland to strengthen this argument, considering their work a 'splendid example of the attitude the proletariat of the oppressor nations should have towards national movements'. ${ }^{21}$ However, Luxemburg theorised that national independence served no useful purpose, being a retrograde step for industrial development in a Polish economy that had become fully integrated with its Russian counterpart. ${ }^{22}$ More fundamentally, it was also an impossible demand to accommodate, as nearly every national claim was based on and resulted in the economic oppression of another national group, and was a damaging

\footnotetext{
${ }^{20}$ V.I. Lenin, The Right of Nations to Self-Determination, (Moscow: 1979), p35.

${ }^{21} \mathrm{~V} . \mathrm{I}$. Lenin, The Right of Nations, p52

22 Rosa Luxemburg, The Industrial Development of Poland,
} 
impediment to the necessary growth of international class consciousness. ${ }^{23}$ The outbreak of war and the collapse of the Second International behind the banners of national patriotism and chauvinism stimulated further thinking on the matter. This was captured in Lenin's 1916 work, Imperialism: the Highest Stage of Capitalism, in which he identified some of the negative political consequences of imperialism upon the European working class movement. In particular was the connection between the 'superprofits' being made by the bourgeois classes through their empires and the reformism of the 'labour aristocracy', which Lenin saw as the main social prop of capitalist rule in Western Europe and the USA. ${ }^{24}$ Imperialism would in time prove to be a hugely influential work, forming the basis for major shifts in international communist strategy in the post-Russian revolution era. However, all of that lay ahead. For now, few international socialists displayed much understanding of the importance of the national question in colonial states or the relationship between nationalism and socialism in colonial states. As a result not many showed much interest in the one national independence rebellion of this period that had a socialist leader, the Easter Rising. Lenin was among the small number that did, defending the rebellion as a genuine insurrection of a section of the Irish petty bourgeoisie and working class, while regretting that it had happened too soon 'before the European revolt of the proletariat had had time to mature' ${ }^{25}$ But his was very much a distant voice at this stage

Harry McShane further noted in his memoirs that the Scottish socialist movement more generally was also divided by the Rising. He described attending socialist meetings in Ayrshire, where opposition to the Rising was expressed and also how the ILP and its

\footnotetext{
${ }^{23}$ Anita Shelton, 'Rosa Luxemburg and the National Question', East European Quarterly, XX1, 3, 1987, p300.

${ }^{24}$ V.I Lenin, Imperialism, the Highest Stage of Capitalism (Moscow: 1982), pp13-14.

${ }^{25}$ Ralph Fox, Marx, Engels, Lenin on the Irish Revolution, (London: 1932), p19
} 
newspaper, Forward - a journal to which Connolly had regularly submitted articlescondemned the Rising. McShane maintained that in Glasgow, it was only the BSP which was fully behind the Rising. ${ }^{26}$ This is plausible as the Glasgow BSP had consistently taken a principled line against imperialism and the war in particular. Its guiding influence and most well-known activist, John Maclean, had just been jailed for his opposition to the war, and had in the past visited Ireland for speaking tours. ${ }^{27}$ Elsewhere, the BSP, which at this stage had just suffered a split over its attitude to the war, ${ }^{28}$ took a line that appeared similar to that of the SLP. The new party newspaper, the Call offered coverage of the Rising and its impact. But the tone of the commentary was not overly sympathetic. In its 18 May edition, the Call noted that the Irish had risen 'without adequate force' and 'like every such Rising', the action had been 'doomed'. Two weeks later the newspaper also appeared to either forget or overlook the principal achievement of Easter Week: the proclamation of the Irish Republic. This happened when the paper discussed comments made by Liberal leader, Asquith, that both home rule and partition be implemented. Asquith's suggestions were described as 'doomed to fail' but apparently only as a result of partition and not because Home Rule itself was an inadequate measure. ${ }^{29}$

The only British socialist organisation which did appear to support the Rising was Sylvia Pankhurst's small Workers' Socialist Federation. In the 13 May edition of the Women's' Dreadnought she described the Rising as 'reckless' but praised it for being 'undoubtedly animated by high ideals'. The Dreadnought highlighted the egalitarian aspects of the

\footnotetext{
${ }^{26}$ Harry McShane, No Mean Fighter, pp82-83

27 Nan Milton, John Maclean, (Glasgow: 2002), p35

28 In April 1916, the pro-war Hyndmanites had been defeated and would later leave the BSP. But as Kendall points out, the new BSP leadership adopted more of a pacifist opposition to the war, and refrained from taking unilateral action against it. Kendall, Revolutionary Movement, p171

${ }^{29}$ The Call, 1 June 1916
} 
Proclamation and noted its commitment to full male and female suffrage. The party also enjoyed something of a coup when one of its members, Patricia Lynch, was able to slip through the military cordon in Dublin and report first hand on the aftermath of the Rising. Her reports remain valuable today for many reasons-not least for the way that they challenge one of the hardy perennials of Irish revisionist historiography-- that the 1916 rebels lacked support and sympathy from the local population. ${ }^{30}$

\section{British Socialists during the Irish War of Independence}

The period after the Rising saw the onset of a revolutionary crisis for the British state in Ireland. Police reports show that as early as June 1916, a growth in support for republicanism was already visible. ${ }^{31}$ Within 18 months, the Irish Volunteers, soon to be known as the Irish Republican Army, (IRA) had been rebuilt and the Irish Parliamentary Party's (IPP) decades-long hegemony within Irish nationalism was unravelling. In April 1918, Conscription was defeated following a campaign that was largely led by the labour and trade union movement. ${ }^{32}$ Eight months later Sinn Féin had swept a large majority of Irish seats in the British General election and in January 1919 declared a rival Irish Parliament and government, Dáil Éireann. This would be followed by a brutal guerrilla war between the IRA and the British state. A key dynamic during this entire period was the unprecedented level of labour militancy. In 1914, there had been 5900 workers involved in strike action, and a total of 290,000 strike days; by 1918 , this had risen to 70,8000 workers and over 1.4 million

\footnotetext{
${ }^{30}$ Women's Dreadnought, 13 May 1916

${ }^{31}$ Fearghal McGarry, The Rising: Ireland's Easter 1916, (Oxford: 2010), p281.

${ }^{32}$ For a recent discussion on the role of the Labour movement in this campaign, see Fiona Devoy McAuliffe, 'Workers Show their Strength; The 1918 Conscription Crisis' in David Convery (eds) Locked Out: A Century of Irish Working Class Life, (Kildare: 2013), pp 75-92
} 
strike days. ${ }^{33}$ In 1919 alone, there were twelve local general strikes ${ }^{34}$, including the famous Limerick Soviet. ${ }^{35}$ From various directions, then, the British writ in Ireland was subject to the strongest of challenges.

During this period, Ireland became a far more pressing issue for the British socialists. As well as the changes in socialist thinking globally brought about by the Bolshevik revolution, this increased concern was a direct response to the escalating violence of the British state and its hypocritical flouting of its own supposed democratic principles. This led to greater contact with Irish revolutionaries, some of which were ephemeral, like that between Captain Jack White and the BSP in the spring of 1918. White had famously trained the Irish Citizen Army and had been jailed for attempting to bring miners in South Wales out on strike in protest against the executions in May 1916. ${ }^{36}$ In April 1918, he appeared on a number of BSP platforms, where he urged British socialists to do more to assist the Irish revolutionaries, chided them for their weakness and maintained that he had not met more than one in a hundred who, when asked to take action in support of Ireland, had not responded with the comment 'what will the government do'? ${ }^{37}$ White's connection to the BSP was perhaps not significant but his advice to them, and the earlier example he had set in 1916 was, as we will see, very much in line with the expectations that the emerging centre of world revolution would also have of its British comrades.

\footnotetext{
33 David Fitzpatrick, 'Strikes in Ireland, 1914-1921, Saothar: Journal of the Irish Labour History Society, 6, (Dublin: 1980), p36.

${ }^{34}$ Emmet O'Connor, Syndicalism in Ireland, 1917-1923, (Dublin: 1988), p25.

${ }^{35}$ For more on the Limerick Soviet, see Liam Cahill, Forgotten Revolution: The Limerick Soviet, 1919, (Dublin: 1991)

${ }^{36}$ White was jailed for three months. See the Daily Mirror, 18 May 1916; Liverpool Echo, 24 May 1916

${ }^{37}$ National Archives (UK) KV 2, 1654, 'British Socialist Party, Report of Openshaw meeting', 27 April 1918,
} 
Perhaps the most significant input from a British Marxist organisation in this period came from the Socialist Labour Party. The SLP by this stage had become less politically sectarian and had also sloughed off its reticence towards the unfolding Irish revolution. Contacts were established with Irish republicans and significant levels of propaganda work were being undertaken. The party was embroiled in a destructive internal crisis over the moves towards the formation of a British Communist Party, ${ }^{38}$ but clearly viewed Ireland as an issue upon which it could distinguish itself from the remainder of the British Left and make progress. On 5 February 1920, the Socialist was clear on the connections between the Irish struggle and the prospects of revolution in Britain:

More and more Ireland is proving itself the storm centre of the British isles...Ireland is a powder magazine, the explosion of which, if carefully timed and organised in harmony with events in the mainland will undoubtedly hoist the shaky fabric of the "glorious" British empire into the air.

One week later, in an article that condemned the British for attempting to provoke another 'Easter' bloodbath, the Socialist again identified a connection between the two struggles: Ireland cannot be successful without the mainland of Britain. Our revolutionary success in the mainland will be assured by the solid support of the Irish working class. We must redouble our efforts on both sides of St George's Channel. We can neither of us afford to be caught unprepared. ${ }^{39}$

In addition to this, there were regular references to James Connolly. For example the cover of the May Day 1920 edition had a montage of images titled 'Communists of the Revolution: Past and Present', which included Connolly, Marx and Luxemburg. Three months later, the party NEC passed a special resolution, which noted:

A subject Ireland is necessary to safeguard the commercial sea-routes of the British Empire...an Independent Irish Republic means the first step in the disintegration of the British Empire at its very

\footnotetext{
${ }^{38}$ The SLP had been involved in negotiations with other socialist groups, which had the aim of establishing a communist party in Britain. The question of whether a communist party should seek affiliation to the Labour Party divided the SLP. The party leadership, including Tom Bell, McManus and Willie Paul were in favour of this, but a majority of the membership were opposed. The leadership was eventually expelled and later helped form the CPGB. The SLP never fully recovered from this trauma.

${ }^{39}$ Socialist, 12 February 1920
} 
centre...the proclamation and successful establishment of such a Republic would be the signal for a united onslaught on British capitalist-imperialism by all of the nations whose necks are under the heel of ruthless militarism stretching from India to Ireland. ${ }^{40}$

The SLP was dismissive of those within the British labour movement who 'merrily' passed resolutions on Ireland, but did little else to stop the British war machine. ${ }^{41}$ By way of contrast, the party did make some efforts at more direct involvement in the struggle. Close links were built with a small clutch of socialists in Belfast, who had split from the ILP and organised themselves into the short-lived Revolutionary Socialist Party of Ireland. One member of this organisation, Kathleen Coyle, penned an occasional column in the Socialist, under the name of 'Selma Sigerson' which was far more scathing of Sinn Féin and its 'neocapitalist' tendencies than most of the offerings from British socialists. ${ }^{42}$ Three other leading figures in this group were John Frederick Hedley, Charles O'Meagher and Simon Greenspon. This trio had all been involved in the famous Belfast general strike of January 1919 and had also been jailed four months later for 'unlawful assembly', after organising a series of socialist meetings in Belfast.

Hedley is of particular interest to our discussion. Born in Goole in 1884, he had been a stoker in the navy but had become a socialist and deserted in 1918, before becoming involved in socialist activity in Belfast. Following his release from jail in the summer of 1919, Hedley became active in the SLP in Sheffield but in January 1920 was arrested again under the Cat and Mouse act and returned to Crumlin Road prison in Belfast. In April, he embarked on his fourth hunger strike in just 12 months, and was eventually released in

\footnotetext{
40 Socialist 19 August 1920

${ }^{41}$ Socialist, 13 January 1921

42 C.D Greaves, the Irish Transport and General Workers' Union: the Formative Years, 1909-1923, (Dublin: 1982), p235. Some of Coyle's writings were republished as Sinn Féin and Socialism by the Cork Workers' Club in 1976
} 
May. A 'Jack' Hedley defence fund was established during this period by the SLP, with his wife contributing updates on his health to the Socialist. Hedley would later become an organiser for the ITGWU and play a leading role in at least three of the major workplace occupations and soviets that were set up by workers in Munster during 1920-1922. ${ }^{43}$ In May 1921, Hedley was sentenced to six months hard labour for making seditious speeches to sailors in Portsmouth, following a secret trial that was held under the provisions of the Emergency Powers Regulations. ${ }^{44}$

In addition to the connections with the Belfast socialists, there were also strong links between the SLP and a group of socialist republicans in Dublin, who in 1919 had briefly taken over the leadership of Socialist Party of Ireland, (SPI) with a view to affiliating it to the newly-established Communist International (Comintern) Most of these socialists had a background in Irish republican activism. The group included 1916 veterans Paddy Stephenson and James Connolly's son, Roddy, but the one who would build closest links with the SLP was Seán McLoughlin. McLoughlin had played a leading role in the Easter Rising and in the post-Rising re-organisation of the Irish Volunteers. ${ }^{45}$ But he was also a socialist and during 1919 made contact with the SLP and began writing letters to the Socialist. During 1920-1921, McLoughlin spent long periods in Scotland and England, undertaking speaking tours that were organised by the SLP. During this time, he joined the SLP and helped develop the organisation's understanding of the Irish Revolution, pushing it to greater efforts in support of the republican struggle. McLoughlin later claimed that he had been asked by Michael Collins to make contacts with the British Left, in order to secure political

\footnotetext{
${ }^{43}$ C.D Greaves, Liam Mellows and the Irish Revolution (London: 1971) pp256, 317

${ }^{44}$ Western Daily Mail, 21 May 1921; Portsmouth Evening News, 20 May 1921

${ }^{45}$ For more on McLoughlin's life and times see Charlie McGuire, Sean McLoughlin: Ireland's Forgotten Revolutionary, (Pontypridd: 2011)
} 
support, as well as material support, in the form of arms and money, for the struggle against British imperialism. ${ }^{46} \mathrm{His}$ efforts are worthy of consideration, because he was one of the very few Marxists who attempted to theorise the relationships both between Irish nationalism and socialism and the Irish and British revolutions. In a significant article published in the Socialist in February 1920, McLoughlin argued that while all socialists needed to support the demand for an Irish republic, they also had to be aware of the contradictory class interests locked within the republican struggle. 'Who is going to rule in an Irish Republic' he asked, 'that will be the rock upon which Sinn Féin is wrecked'. Developing Connolly's 1916 'hold onto your rifles' instruction to the ICA, McLoughlin maintained that while socialists would assist republicans in the struggle against British imperialism, 'the fight to overthrow British power in Ireland may not be half as bitterly contested as the fight between the Irish working class and Irish middle class for control of the country'. He concluded by urging socialists to continue the Irish revolution, 'as the Russians had' beyond 'the point marked by their exploiters', towards the workers republic. ${ }^{47}$ Shortly afterwards, in a report sent to the Comintern sub-bureau in Amsterdam, McLoughlin analysed closely the various organisations within the Irish independence and labour movements, dismissing the Sinn Féin leaders as 'people of a bourgeois outlook' and pinning his hopes on the 'proletarian' IRA rank-and file, who, he claimed, could be won to a position of active support for socialism. ${ }^{48}$ These tensions between Irish nationalism and socialism would be revealed more clearly and explored in more depth by socialists following

\footnotetext{
${ }^{46}$ National Archives (Ireland), Bureau of Military History, Witness Statement 290, Sean McLoughlin. All BMH witness statements can now be accessed online at: http://www.bureauofmilitaryhistory.ie/index.html ${ }^{47}$ Sean McLoughlin, 'Sinn Féin and the Irish Workers, Socialist, 26 February 1920

${ }^{48}$ National Library Ireland, William O'Brien Papers, 15,674 (3), 'Report of the Political Organisations of the Working Class; also published in Socialist, 27 May 1920
} 
the signing of the Treaty in December 1921, but McLoughlin's articles constituted an early attempt to grapple with the problem.

On the relationship between the Irish and British revolutions, McLoughlin argued that the Irish struggle was linked to that of the struggle for socialism in Britain, through being directed against the same ruling class. But unlike virtually all socialists of that era, McLoughlin felt that socialism would be established in Ireland before Britain. He believed that this would detonate uprisings throughout the British Empire, which would in turn precipitate the destruction of capitalism in Britain itself. McLoughlin believed that the triumph of socialism in Britain would be the only way that an Irish socialist republic could be sure of long term survival. As a result of this analysis, he urged Irish and British workers to support both Irish independence, and the socialist movements in both countries. ${ }^{49}$

Most of McLoughlin's political activity in Britain was dedicated to this objective. His meetings were held initially in the main cities and towns in Scotland, but spread to the North of England and eventually went as far south as Coventry. These gatherings often drew huge crowds, sometimes several thousand strong. In his speeches, he continued to make the connection between the interests of Irish and British workers and would often warn his audiences that the Black and Tans of Ireland today would be the Black and Tans in Scottish and English cities tomorrow. McLoughlin's membership of the SLP would later end in acrimony, but forms an important episode in the story of the connections between British and Irish revolutionaries in this period..$^{50}$

\footnotetext{
${ }^{49}$ For more detail, see The Socialist, 27 May 1920

50 McLoughlin was expelled from the SLP in September 1921, following the circulation of a false rumour that he was a police agent. He returned to Ireland in July 1922 and later joined both the CPI and IRA.
} 
Many of these SLP meetings in Scotland and England were organised as 'Hands off Ireland' events. The regular use of this slogan was a clear reference to the successful 'Hands off Russia' campaign which had been supported by all sections of the British labour movement, including some trade union leaders, but which on the ground was driven by communists. ${ }^{51}$ The highpoints of the campaign were the stopping of the Jolly George, on 10 May 1920, shortly after the Polish invasion of Russia and the mass demonstrations organised by hundreds of 'councils of action' three months later, which pushed the TUC and Labour Party leadership to threaten a general strike. ${ }^{52}$ Challinor points out how the CPGB (or those who would soon form it) effectively excluded the SLP from participation in this organisation, at least at leadership level, and that this was another reason behind the party's more concentrated focus on Ireland. ${ }^{53}$

But the SLP was not the only grouping involved in Irish solidarity work. Another segment of the Scottish Left, organised around John Maclean, also engaged in such activity. As noted earlier, Maclean had a long-standing interest in Ireland, first visiting the country in 1907, where he took part in a speaking tour in support of the Belfast Dockers who were on strike led by Jim Larkin. Maclean also visited Ireland in 1919 for a short speaking tour in the summer of 1919, where he shared platforms with Seán McLoughlin, among others. ${ }^{54}$ Maclean's interest in the Irish republican struggle had intensified by this stage. He regarded this struggle as constituting a severe crisis for British imperialism and capitalism, but was also interested in the way that republicanism and socialism could be blended, and how this

\footnotetext{
${ }^{51}$ James Klugmann, History of the Communist Party of Great Britain, Formation and Early Years, 1919-1924, (London: 1968), p79

${ }^{52}$ Klugmann, History, pp79-85

${ }^{53}$ Challinor, Origins, p265

${ }^{54}$ Nan Milton, John MacLean, p209
} 
might be applied in a Scottish context. ${ }^{55}$ Maclean held regular 'Hands off Ireland' meetings, including one at Motherwell in July 1920, which was attended by between 2000-3000 people, where he and ally James McDougall called for the withdrawal of British troops and suggested that the Lanarkshire miners go on strike in support of this demand. ${ }^{56}$ Seven months later, the Giffnock miners would do just that, stopping for 24 hours 'in protest against British atrocities in Ireland' and calling on the remainder of the Lanarkshire coalfield to do likewise. ${ }^{57}$

In addition to the meetings, there was also propaganda, including most famously, The Irish Tragedy: Scotland's Disgrace, a 1920 pamphlet that sold around 20,000 copies, and represented Maclean's most detailed analysis of the issue. In this work, Maclean outlined a materialist basis for his support for Irish independence and displayed the connections he perceived between that struggle, and the struggle for socialism in Britain. Like some within the SLP, Maclean regarded the Irish working class as the principal force within the revolutionary struggle and argued that a successful Irish independence struggle would be the prelude to an Irish socialist republic, which would weaken capitalism everywhere. Should Ireland get a Republic the class war will then burst out and be fought till Irish Labour wins... This new phase in Irish life ought to be the inciting influence to British Labour...Ireland's victory is obviously the prelude to Labour's triumph throughout the world..$^{58}$

Maclean later took aim at those British socialists who could not see the geo-political significance of the Irish independence struggle against British imperialism:

\footnotetext{
${ }^{55}$ For a more detailed consideration of Maclean's views on the Irish and Scottish national questions, see David Howell A Lost Left: Three Studies in Socialism and Nationalism, (Chicago: 1986) pp210-217

${ }^{56}$ Motherwell Times, 9 July 1920

57 The Socialist, 27 January 1921

58 John Maclean, The Irish Tragedy: Scotland's Disgrace, (London: 1976), p9
} 
The Irish situation obviously is the most revolutionary that has ever arisen in British history, but unfortunately lads who fancy themselves the only revolutionaries are too stupid or too obsessed with some little crochet to see the tight corner the Irish are placing the British in...The Irish Sinn Féiners, who make no profession of socialism or communism and who are at best non-socialists, are doing more to help Russia and the Revolution than all we professed Marxians in Britain. ${ }^{59}$

The efforts of the SLP in 1920-21 and John Maclean's BSP and Tramp Trust groups are among the most significant made by the British Left during the Irish Revolution. These efforts also included involvement by a group of SLP activists in a strike in Dublin, on the issue of Jim Larkin's imprisonment in the USA. ${ }^{60}$ But by themselves, they were efforts that could not have a mass impact. Not only were these small forces, but they were also in decline at this point. As a result of its crisis over the formation of the CPGB, the SLP was struggling to survive and had effectively disappeared by the end of 1922 . Maclean, brutalised by repeated imprisonment and politically marginalised by the CPGB, eventually died aged just 44 in November 1923. The larger organisations of the labour movement of course did have far more potential. But here, there was little will to act in such a fashion. Shortly after the start of the munitions boycott by Irish trade unionists in May 1920, a special TUC conference was organised to discuss Ireland. At this meeting, the Miners showed willingness to act by passing a resolution that called for industrial action, in the event of the government failing to end both the military occupation of Ireland, and the production of war materiel. But this resolution was neutralised by the NUR leader, JH Thomas, who ensured that the conference passed another resolution calling for a truce and the establishment of an Irish parliament with dominion status-a settlement that no section of the Irish revolutionary movement was advocating. Thomas was able to argue that the Miners' resolution would be enacted only if the government failed to move on the NUR

\footnotetext{
${ }^{59}$ David Howell, A Lost Left, p212

${ }^{60}$ Socialist, 5 August 1920
} 
proposal. ${ }^{61}$ But when it is considered that Thomas had already met with Lloyd George the previous month and agreed with him that the munitions boycott was tantamount to a 'war upon the government', it is clear that he had little intention of supporting strike action, no matter that the government did or didn't do. ${ }^{62}$ The Socialist in particular, recognised the crucial role that the British working class could play in support of the Irish independence struggle. ${ }^{63}$ It duly criticised Thomas for failing to support the munitions boycott, ${ }^{64}$ but it made little difference; in the period ahead, the British state would be responsible for some appalling acts of violence in Ireland, ${ }^{65}$ but there would be no action against it by the trade union leaders.

\section{Partition}

During 1920-1921, the final outcome of the Irish Revolution remained unclear, but there were powerful forces within Irish society and the British state threatening to divert it away from the type of thoroughgoing social and political transformation envisaged by the more radical socialist republicans. A key debate in this respect was that surrounding the possible partition of Ireland. The suggestion that some of the Ulster counties be excluded from Home Rule had been mooted by the British government in 1913, and would remain central to their approach until the eventual creation of Northern Ireland in 1920-21. The crisis threw into relief some of the complexities of the Irish national question. It revealed substantial opposition to Irish independence from a considerable section of the protestant working

\footnotetext{
61 Times, 14 July 1920

62 Times, 6 June 1920.

63 The Socialist 10 June 1920

64 The Socialist, 24 June 1920

${ }^{65}$ Many of which are detailed in the report of the Labour Commission to Ireland, (London: 1921), passim
} 
class, which in turn would constitute a serious challenge to socialist thinking and practice in the period ahead.

James Connolly had written extensively on the threat of partition in 1913-14. His famous prediction that partition would generate a 'carnival of reaction' was an argument based primarily on material, class considerations; he was concerned about the impact the measure would have on Irish workers and feared it would 'destroy' the 'oncoming unity of the labour movement' ${ }^{66}$ These class-based fears were accompanied with sharp attacks on what Connolly considered to be the phoney nationalism of the IPP who had reluctantly accepted the measure, and the cynicism of the Ulster Unionist bourgeoisie, who stood to benefit from it. Connolly remained convinced that the Irish capitalist class was too weak to lead a struggle for full national economic and political independence, and that only Irish workers could achieve this. But while there was truth in his depiction of the Irish bourgeoisie--no section of this class, north or south, was able to lead this struggle to a successful conclusion- Connolly never did tease out precisely why its north-eastern component was so supportive of the union and so uninterested in economic development elsewhere on the island. Rather than probe the connections of this class to British capitalist-imperialism, he appeared to regard unionism as based mainly on sectarianism and held out a hope that the exploited protestant working class would eventually recognise its true class interests and reject those who 'hide their sweatshops behind Orange flags' ${ }^{67}$ Connolly's ideas and approach would provide the framework for most Irish and British socialists in the post 1916 period, in their attempts to understand and deal with the issue.

\footnotetext{
${ }^{66}$ Irish Worker, 14 March 1914

${ }^{67}$ Forward, 11 March 1911.
} 
Throughout these years, the entire Irish Left would remain hostile to the prospect of partition. Even in Belfast, which had a mainly protestant labour and socialist movement, all genuine labour and socialist political organisations were opposed to the measure and supported the principle of Irish self-government on a 32-county basis. ${ }^{68}$ The reconstituted Belfast Labour Party was the principal socialist organisation in the city and in both the 1918 general election and 1920 Corporation elections, had successfully stood on such a platform. ${ }^{69}$ Like their Irish counterparts, British Marxist organisations were hostile to the possibility of partition and also tended to the view that orangeism and unionism were ideological creations of the northern bourgeoisie, constructed to control and dupe the protestant working class. The BSP had made clear its objections to unionism and the possibility of partition in 1916. Dismissing protestant religious fears as 'a bogey largely created for political purposes', the Call described as 'absurd' the argument that Ulster was a homogenous unit. The newspaper outlined Ulster's economic importance to the rest of Ireland and concluded that partition would be akin to 'permanently depriving France of the territory now occupied by the Germans'.$^{70}$

Sectarian violence reached exceptionally high levels during this period. In Belfast alone, 453 people were killed in the 2-year period during July 1920-July 1922. Although they made up just $25 \%$ of the city's population, 257 of these victims were Catholics. Around a quarter of Belfast's catholic population also lost their jobs, and 23,000 were forced out of their

\footnotetext{
${ }^{68}$ Genuine, i.e. not the Ulster Unionist Labour Association, a yellow, bogus labour political organisation which was established by the Ulster Unionist Party in 1918 in order to maintain its grip over the protestant working class.

${ }^{69}$ The four Labour candidates stood in predominantly protestant seats in 1918, receiving around a quarter of the votes. In 1920, Labour performed exceptionally well, gaining over 17,000 votes and 12 seats, making it the official opposition to the Unionists on Belfast Corporation

${ }^{70}$ The Call, 1 June 1916
} 
homes. ${ }^{71}$ Belfast Labour was also routed, with its North Belfast hall being burned down by loyalists and its candidates physically prevented from campaigning in the inaugural 1921 Northern Ireland parliament elections. This upsurge in political violence was commented upon by the British socialist press, but a deeper inability to explain the popularity of unionism within protestant society remained evident. Instead, unionism continued to be viewed as a 'yarn', spun by the industrialists to entrap the protestant working class. It continued to be viewed as a superficial ideology from which protestant workers might be detached. In September 1920, the Socialist rightly noted how the shipyard expulsions had included thousands of protestant socialists and trade unionists. It condemned the 'Carson Clique' for fomenting this violence in order to protect their class interests. As for those who carried out the attacks, they were dismissed as 'Orange fanatics' and the 'worst product civilisation has known'72. A slightly more developed view of unionism was offered a year later by the CPGB's Willie Paul. In his pamphlet, The Irish Crisis, he pointed out how the economic interests of the northern bourgeoisie were 'intertwined' with those of the British capitalism generally, and how this bourgeoisie was reliant for its continued prosperity on unfettered access to imperial markets. ${ }^{73}$ But the materialism stopped there. The rest of Paul's argument constituted something of a flight both from Connolly, and reality. He predicted that during a 'revolutionary crisis' the 'peculiar psychology of Orangeism' with its 'fierce and violent hatred' of its enemies' might result in protestant workers turning against the unionist bourgeoisie and moving towards socialism. ${ }^{74}$ To say that this was wishful thinking is perhaps an understatement. But throughout this entire period, the possibility that a key section of the protestant working class might exist as a labour aristocracy and

\footnotetext{
${ }^{71}$ Michael Farrell, Northern Ireland the Orange State, (London: 1980), p62.

72 The Socialist, 16 September 1920

${ }^{73}$ William Paul, The Irish Crisis, (London: 1921), p1

${ }^{74}$ Paul, Irish Crisis, pp2-3.
} 
consider its marginal material privileges to be bound up with Unionism was never interrogated by any section of the British Left.

\section{Communists, the Treaty and the Irish Civil War}

By 1921, the CPGB had become the dominant British Marxist organisation. Launched in August 1920, it was composed mainly of the BSP, along with sprinklings of other smaller groups. Other developments were also taking place. In the aftermath of the Russian Revolution, a new Communist International had been formed, which identified the national and colonial question as a subject of prime importance. As indicated above, Lenin's Imperialism: the Highest Stage of Capitalism had signposted this development. Flowing from his analysis was the view that the world had been divided into a small number of oppressor states and a large number of oppressed countries. For the first time, this brought the focus of European socialism onto those oppressed countries, which were now seen as important to the prospects of destroying capitalism globally. At the 1920 Comintern Congress, the national and colonial question was examined in depth. Distinctions were drawn between reactionary and progressive forms of nationalism and a set of theses drawn up which committed communists from imperial states to actively support revolutionary nationalist movements in colonies. ${ }^{75}$

In relation to Ireland, this suggested that British communists should offer active support for the struggle of the IRA against the British state. As if to clarify what was actually meant -and not meant--by this, Karl Radek offered the following prescription:

The International will not judge the British comrades by the articles they write in the Call and the Workers' Dreadnought but by the number of comrades who are thrown in gaol for agitating in the

\footnotetext{
${ }^{75}$ Lenin, Speeches at Congresses of the Communist International ${ }_{2}$ Moscow (1972) p57.
} 
colonial countries. We would point out to the British comrades that it is their duty to help the Irish movement with all their strength, that it is their duty to agitate among British troops, that it is their duty to use all their resources to block the policy that the British transport and rail unions are at present pursuing of permitting troop transports to be shipped to Ireland. It is very easy at the moment to speak out in Britain against intervention in Russia, since even the bourgeois left is against it. It is harder for the British comrades to take up the cause of Irish independence and anti-militarist activity. We have a right to demand this difficult work of the British comrades. ${ }^{76}$

The CPGB had in its ranks a number of theoreticians with an interest in Irish politics, but appeared reluctant to prioritise Ireland over Russia in this fashion. In his first comment on Ireland in the Communist, T.A. Jackson made it clear that this would not happen. He argued that while the Bolshevik forces were part of the 'World Army of Proletarian Revolution' the Irish question was at root a national question. With CPGB resources finite, the question 'was one of degree and urgency and on the grounds of superior urgency alone we can justify our concentration on the Russian aspects of the struggle'. ${ }^{77}$

The 1920 Comintern Congress was also significant because the Irish communists themselves had taken part. Their emergence would provide another ingredient to the revolutionary mix. Two delegates, Roddy Connolly and Éadhmonn MacAlpine, made the long journey to Petrograd and were involved in the discussions on the national and colonial question. They clearly saw in the theses a confirmation of their own strategy, which had been based around assisting Irish republicans in a clandestine fashion. ${ }^{78}$ The Irish communists, however, would not enjoy a fruitful relationship with their British counterparts. Connolly appeared unimpressed with the British communists from the earliest point, and later reflected that their 'mode of political life was far removed from anything like illegal or conspiratorial

\footnotetext{
${ }^{76}$ David Reed, Ireland: The Key, pp71-72.

77 Communist, 9 September 1920

${ }^{78 \prime}$ C Comrade X' [Roddy Connolly], Report of the Proceedings of the Second Comintern Congress,_London (1920) pp143-44.
} 
activity.' 79 In February 1921, whilst in Moscow, he submitted a report to the Comintern Executive (ECCI) which criticised the British communists for their alleged inactivity on the Irish question, noting that how, beyond the press articles, they had 'taken very little interest in helping the Irish communists.' In this report, Connolly held out the hope that a Liaison Committee of the two parties could be established, which would 'strengthen the connection between them ${ }^{80}$ However, relations between Irish and British communists did not improve. In August 1921, the CPGB started an Irish Workers' Republic column in the Communist, which was originally penned by Connolly. At this time, the Irish communists were engaged in a final attempt to gain control of the SPI. In his articles, Connolly made caustic references to the leaders of the party, Tom Johnson and William O'Brien, who were also the two leading figures in the Irish Labour Party and trade union movement at this point. Supporting communists and exposing the manifold shortcomings of social democracy was a basic founding principle of the Third International, but rather than support Connolly against the Irish social democrats, the CPGB, irked by the tone of his remarks, decided to remove him as a contributor, commenting that they had 'neither preference nor choice' between these 'rival personalities' ${ }^{81}$ It is true that some of Connolly's remarks verged on the juvenile but this was still an unprincipled approach by the CPGB and opened up a breach that would never be properly healed.

In the subsequent period, British communists would develop little by way of a formal relationship with the $\mathrm{CPI}$, preferring to cultivate links with republicans and Labour activists. With a Truce agreed between the republican leaders and the British state in July 1921, the

\footnotetext{
79 Tape of Roddy Connolly speech to the Ireland-USSR Friendship society, October 1974, courtesy of Mike Milotte.

${ }^{80}$ Russian State Social and Political Archives (RGASPI), 495/89/10/2-3, Report to Comrade Kobietsky for the Comintern Executive by Roddy Connolly, 10 February 1921.

${ }^{81}$ Communist, 15 October 1921
} 
political climate in Ireland became more settled, allowing for connections to be strengthened between the CPGB and some leading republicans. In November 1921, T.A. Jackson visited Dublin and also met with the leaders of a number of other organisations, including the ITGWU, ICA, as well as the local communists. ${ }^{82}$ However, Jackson and the CPGB's actual understanding of the Irish Revolution, specifically the relationship between Irish republicanism and socialism, lacked the clarity of the work that had been published by Seán McLoughlin in particular in the Socialist and appeared uncertain and inconsistent. For example, in April, he argued that socialists should support Irish independence because it would pave the way for socialism. He contended that whilst an Irish republic would not be socialist, it was a necessary step towards the Irish working class 'freeing itself from the need to subordinate their class interests to the cause of national unity. ${ }^{83}$ It was an analysis dismissed as 'Menshevist' by his fellow CPGB member, P.L Gray, who argued that it would be a mistake to offer uncritical support to an Irish capitalist republic and how in their propaganda, British communists needed to highlight the dangers of nationalism and reinforce how the 'Cause of Dublin Castle was the Cause of the British Capitalists'. ${ }^{84}$

The main focus remained the negotiations between republican leaders and the British state. In December 1921 this eventually produced a Treaty that established a 26 county Irish Free State within the British Empire, and also copper-fastened partition. According to his own accounts, Willie Gallacher was tipped off about the agreement and travelled to Dublin, where he advised republicans to oppose the Treaty, arrest the plenipotentiaries who had signed it and issue a proclamation with some CPGB-inspired social policies. Gallacher was

\footnotetext{
${ }^{82}$ Communist, 26 November 1921

${ }^{83}$ Communist, 2 April 1921

${ }^{84}$ Communist, 14 April 1921
} 
welcomed as a friend by Cathal Brugha, Liam Mellows and Rory O'Connor, but-not surprisingly-his suggestions were politely declined. ${ }^{85}$ The CPGB itself had expected that the talks might break down on the issue of the oath, and appeared surprised by the Treaty. Uncertainty characterised its early attempts at analysis. In his first post-Treaty deliberation, Jackson criticised the British government for refusing to allow an Irish republic and for continuing to support unionism. The British had, he argued 'gained much and lost little...except their dignity and honour'. His article, however, said little about the Treaty itself, or the class interests that it seemed to uphold, beyond the somewhat vague observation that Irish workers would be 'disappointed' by it. ${ }^{86}$ The contrast with the CPI position was striking. The Irish communists clearly believed that the class divides within the nationalist struggle, which the Sinn Féin leaders had attempted to conceal, had now been blown open. On the same day of the Jackson article, the Irish communist newspaper offered a withering class analysis, which depicted Michael Collins as an 'imperialist careerist' and forecast 'civil war and social hell' should the agreement be ratified. ${ }^{87}$

In the following week's edition, Jackson displayed again that he was out of touch with Irish communist thinking, when he stated that while nobody pretended to like the Treaty wholly, 'nobody denied that in its substance it represented a gain on 1914'. Jackson continued that 'those who should be qualified to judge' had no faith in the ability of republicans to maintain a military struggle. He indicated that an economic revival as a result of peace might take place, and that this would open up class differences and the emergence of a

\footnotetext{
${ }^{85}$ Greaves, Liam Mellows, pp268-69

${ }^{86}$ Communist, 17 December 1921

${ }^{87}$ Workers Republic, 17 December 1921
} 
proletarian party. ${ }^{88}$ Much of this was at odds with the position of the CPI, who even at this early stage were now predicting and preparing for civil war. However, one week later, the CPGB executive released a statement which displayed a substantial shift towards the Irish communist position. Here, the Treaty was redefined as an agreement forced upon Ireland by British imperialism and designed to safeguard Britain's imperialist interests. The statement made clear that the CPGB associated itself with the Communist Party of Ireland analysis 'in its refusal to recognise this Treaty as anything but the death-knell of the Irish Republic. ${ }^{89}$

Clearly then, the CPGB position on the Treaty had been confused and diffident. The strident analysis later praised by Reed and Bell emerged only after the party was shunted into line with the CPI position. In April 1922, the political picture in Ireland seemed to become clearer, if more tense, when a section of the IRA, which included socialist republicans Liam Mellows and Peadar O'Donnell, seized the Four Courts in Dublin. As well as being the centre of the Free State's judicial system, the takeover had an obvious symbolism, in that it had previously been occupied by republicans during the Rising. Around the same time, CPI leader Connolly travelled to Germany in an attempt to regularise relations between the Irish communists and the $\mathrm{ECCl}$. His communications here also offer more insights into Irish communist relations with their British comrades. In his report, Connolly continued to complain that the CPGB had been of no assistance to the CPI or the Irish revolutionary struggle. 'They have helped us in no way financially, materially, morally', he pointed out,

\footnotetext{
${ }^{88}$ The Communist, 24 December 1921

89 The Communist, 31 December 1921
} 
'despite all the theses they...do not help our press, carry out no propaganda among British soldiers in Ireland'. 90

The eventual outbreak of Civil War in June 1922 created a political environment fraught with danger for the communists. The context in which it occurred, where neither the Treatyites nor anti-Treatyites had made much reference to social or economic issues, served to confuse and divide workers. By any normal standards, this was not conducive to the development of working class politics. But the communists did not see it like that. On the contrary, as a result of the bourgeois class forces that it considered stacked up behind the Free State regime, the CPI saw in the Civil War a historic opportunity to build up its political strength. It believed that the anti-Treaty republicans might be persuaded to shift to the Left, in order to garner the support of the working class for the Republic. The ECCl shared this view and in the aftermath of the outbreak of conflict, it intervened. $\mathrm{ECCl}$ representative, Mikhail Borodin, was dispatched to London. On 14 July he had a meeting with the leaders of both the British and Irish communist parties and on 15 July interviewed the Irish leaders separately. ${ }^{91}$ The purpose of these meetings was to review the situation in Ireland 'with a view to working out a programme to embrace the various groups and classes that make up the Irish people.' ${ }^{92}$ The outcome of this in the immediate term was a 10-point socialist programme, which Roddy Connolly and Seán McLoughlin presented to anti-Treaty IRA leaders a week later in Fermoy, County Cork. ${ }^{93}$ According to Connolly, Lynch was sympathetic, but outlined the primacy of the military struggle. A second outcome of this

\footnotetext{
${ }^{90}$ RGASPI, 5/3/581/9-17, Report to the Comintern on the Irish Party, R.Connolly, Berlin, 12 April 1922 ${ }^{91}$ RGASPI, 495/89/13-6/10, Borodin Interviews Delegates from the Irish Party, 15 July 1922.

92 National Archives (UK) CAB 24/138/cp4132, Report on the Revolutionary Organisations in the United Kingdom, 27 July 1922.

${ }^{93}$ Mike Milotte, 'Communist Politics in Ireland 1916-45', PhD thesis, (1977) p110.
} 
meeting was the establishment of more formal relations between the two parties. CPI official, George Pollock stayed in London, to help out with the production of the Workers' Republic paper, which was banned in Ireland. A room in King St was rented from the CPGB to assist with this task.

Over the next few months, the communists made strenuous efforts to influence and assist the IRA. Seán McLoughlin rejoined the IRA and led a flying column in Limerick. Connolly travelled to Germany in an unsuccessful attempt to secure an arms deal for the republicans. The CPGB also did its best to influence the IRA directly. In September, McManus and JT Murphy travelled to Dublin to meet with the IRA leadership. There, they presented the republican leaders with a social programme similar to that drawn up earlier by Connolly and McLoughlin. The CPGB leaders reported the response as 'excellent' and stated that many republicans were willing to support communism. An agreement was signed between the 2 delegations, pending acceptance by their respective executives. The subsequent CPGB perspective was optimistic in the extreme:

If by every possible means, military, economic, political, help can be rendered the IRA by the communist movement, thus demonstrating by deed the fundamental unity of purpose in their movement and the struggle towards communism, the future of the republican forces is one with ours. $^{94}$

Pollock may have accompanied the British communists on this trip. In 1948, he recalled a 1922 meeting with two British communists and IRA leaders. Pollock insisted that at this meeting the proposition was put to the IRA that they popularise the social programme and establish a provisional government in the south. He claimed that IRA Quartermaster, Tom Derrig, whilst repeating the line about the importance of the military struggle, nonetheless

94 RGASPI, untitled CPGB report to $\mathrm{ECCl}, 495 / 89 / 13 / 82-84$. 
suggested that the communists go ahead and set up such a government, 'promising that it would have the support and protection of the IRA. ${ }^{95}$ However, despite the optimism of the communists, the Civil War was proving disastrous for the IRA. The Free State took control of Dublin after one week of heavy fighting and by mid-August had dislodged the republicans from their remaining strongholds further south. From that point onwards the IRA was forced into a guerrilla campaign, which although partly successful against the British, was unlikely to prevail in the zero-sum battle context of civil war. By October, the tide was flowing strongly in the direction of the Free State. Feeling that it was now possible to strangle IRA resistance completely, the regime announced the establishment of military courts with the power to pass death sentences. In November 1922, the executions began.

In October, a delegation of seven CPI members attended a CPGB conference at Battersea Town Hall. Their aim was to secure a greater level of support and involvement from the British party. At the conference, a resolution was passed, which 'heartily agreed' with the analysis and strategy of the CPI. This of course was based on continued communist involvement in and support for the anti-Treaty IRA. Whatever about the sagacity of such a policy, the CPGB support of the CPI position did suggest a more positive state of affairs between the two parties. However, it was a facade. Underneath, the relationship was close to breaking point. McManus and Murphy were now of the view that the only obstacle to the recruitment of left-wing Irish republicans and labour activists to communism was the chaotic CPI itself. ${ }^{96}$ On the other hand, the Irish communists remained dissatisfied with the British party, claiming that all they were getting by way of help were 'pious resolutions.' Connolly spoke at Battersea and in his speech appealed to British communists for assistance

\footnotetext{
${ }^{95}$ Irish People, 14 February 1948.

${ }^{96}$ RGASPI, untitled CPGB report to $\mathrm{ECCl}, 495 / 89 / 13 / 82-84$
} 
in the propaganda work against the Free State and 'imperial England'. ${ }^{97}$ In response, the CPGB committed itself to the creation of 'Hands off Ireland' committees, which were designed to prevent the transport of war material to the Free State. ${ }^{98}$ Later, there was also talk by the CPGB of organising a freeze on exports to the Free State. ${ }^{99}$ This was very much the type of activity the Comintern wished to see from British communists, but the commitment appeared to be purely verbal. No 'Hands off Ireland' activity took place and no freeze on exports to the Free State was attempted. The CPGB would be later criticised by Moscow for its lack of input into the Irish revolution. ${ }^{100}$ But by that stage, the CPI, and indeed the Irish Revolution itself, would have long passed into history.

The remainder of the story of British communism and the Irish revolution is an unhappy one. Relations between the CPI and CPGB worsened. The IRA was effectively defeated by December 1922 and although the Civil War would continue into April 1923, its outcome was not in doubt. The CPI, small, never particularly stable, and unable to speak with just one voice on what constituted the appropriate level of communist involvement in the republican struggle, toiled in this difficult environment. The party became more divided in the aftermath of the 1922 Comintern Congress, following a shift in strategy by the ECCl, which encouraged communists to withdraw from active involvement in the IRA and offer only 'moral support' to republicans. ${ }^{101}$ One casualty of this division was Connolly, who lost his

\footnotetext{
${ }^{97}$ National Archives (UK) Report on the Revolutionary Organisations in the United Kingdom, CAB 24/139/cp4292, 26 October1922.

98 RGASPI, Report of the CPI to the ECCI from October 1921 to October 1922, 495/89-16/69.

99 Labour History Archive and Study Centre, James Klugmann Papers, untitled notes for history of the CPGB, $\mathrm{CP} /$ Ind/Klug/03/05

${ }^{100} \mathrm{ECCl}$, The Communist International between the Fourth and Fifth Congresses, London, (1924), p37. This report noted that the $\mathrm{CPI}$ (which was by then defunct) needed more 'material support' from the CPGB. ${ }^{101}$ RGASPI, 495/89/11-6/7, Resolution of the ECCI Presidium on the Irish Question, 13 December 1922.
} 
leadership of the party, being temporarily replaced by former CPGB activist, ABF White. ${ }^{102}$ White had no experience of Irish politics and her installation as leader could only have come through CPGB pressure. Throughout this period, the CPGB played an unfortunate role in deepening the crisis of the $\mathrm{CPI}$, setting itself up as an adjudicator on the precise definition of 'moral support' and dispatching Tom Bell to the reconvened CPI conference in February 1923 to ensure that the Irish communists accepted this definition. ${ }^{103}$ By the end of 1923 , the CPGB was in cahoots with the recently-returned Jim Larkin, clearing the way for the final dissolution of the CPI. But by this stage, the Irish Revolution was long gone. Republicanism had been battered to defeat and the Left had been vanquished. British communists would be involved for a period thereafter in the attempt to build an alternative to Free State neocolonialism and Orange reaction, but assessment of these efforts is beyond the scope of this article.

\section{Conclusion}

On the eve of his execution in May 1916, James Connolly had an emotive final meeting with his wife Lillie and eldest daughter, Nora. During the visit, Connolly, reflecting on his actions, and what he knew to be the outlook of the British Left, asked Nora if she had seen any of the socialist newspapers. When Nora replied that she had not, Connolly retorted 'They will never understand why I'm here...they will all forget I am an Irishman'. ${ }^{104}$ As we have seen, these would prove to be prophetic words, because in 1916, very few socialists did understand why James Connolly had ended up in the GPO. Most saw the Rising as a nationalist rebellion, an act of militarism, which could not serve working class interests.

\footnotetext{
102 RGASPI, 495/89/22-12/17. Resignation of Roddy Connolly to secretary of ECCl, 20 February 1923.

${ }^{103}$ RGASPI, 495/89/22/35-36, ABF White and JJ O'Leary to Comintern, 22 August 1923

${ }^{104}$ C.D. Greaves, The Life and Times of James Connolly, (London: 1961), p420
} 
Attitudes would change. Throughout much of the ensuing Irish revolutionary period, British socialists would become more aware of the reasons behind Connolly's actions in 1916, more able to distinguish between reactionary bourgeois nationalism and revolutionary antiimperialism, more understanding of the connections that existed between revolution in the colonies and socialism in the metropolitan states themselves. But how should their efforts be judged and what legacy, if any, did it create?

1916 can be seen as a low point for British socialism in its understanding of the realities of Irish revolutionary politics. Marx and Engels may well have offered a theoretical and practical guide to the Irish national question for British socialists, but it is clear that in 1916, the British Left's response owed more to the ideas and thinking of the Second International-the same International that in 1907 had debated the merits and demerits of a 'socialist colonial policy' ${ }^{105}$ and the same brand of socialism that in 1914 would watch on, and in many instances cheer, as the European working class marched to the killing fields of France and Belgium. The need for a more penetrating analysis of the relationship between nationalism and socialism in colonial states, and the notion that the political terrain of a colonial state differed to that of a colonising state, and required a different response from socialists, was not widely understood or accepted by European socialists in this era-and certainly not by most British socialists.

The violence of the British state and its decision to meet a popular movement for Irish freedom with force and repression eventually brought about a change in the attitudes of the British Left. The global context was also different by the stage. The first successful

105 Neil Redfern, Class or Nation, p20 
socialist revolution had taken place. Coupled with this was a developing understanding of the importance of the national and colonial questions. This led to greater emphasis on the Irish independence struggle, and greater support for it. During the War of Independence, the most significant organisation was the SLP. Unlike other groupings, the SLP forged direct links with sections of the Irish revolutionary movement. The party based its support for Irish freedom on materialist grounds and appeared more aware of the connection between the anti-imperialist struggle in Ireland and the struggle for socialism in Britain. A similar approach was also in evidence from John Maclean and his small band of revolutionary socialists in Glasgow. But In both instances, the organisation was weak, and the influence was limited. The SLP was finished by 1922 and Maclean would be dead by 1923.

The responsibility for organising British revolutionary socialism's involvement in the Irish Revolution passed to the CPGB. The organisation had in its ranks a number of leading activists and theoreticians with a long-standing interest in Irish revolutionary politics. The CPGB was small by international communist standards, but still had a membership of around 12,000 - which made it several times larger than that of the combined forces of the SLP and Maclean. Moreover, it could also draw on the support and resources of the Communist International, which had identified a successful Irish anti-imperialist struggle as central to one of its most important strategic aims--the weakening of the global power of British imperialism.

However, the CPGB would have a more restricted input into the Irish revolution. The organisation did produce propaganda and attempted to build a rationale for socialist support of the Irish independence struggle. The CPGB also made connections with some 
Irish republican leaders and were treated with consideration by them, even if their communist prescriptions were gently ignored. On the other hand, the CPGB did not make any attempt to organise Hands off Ireland activity. Neither did it adopt a policy of agitating among British troops. As we have seen, there were isolated instances of British socialists taking part in such activity. But these tended to be individuals with no connection to the CPGB. If the British communist contribution to the Irish revolution was to be measured by the number of British communists gaoled for such activity, then the judgement would be a harsh one indeed.

The Russian connection was an undoubted source of strength to British and Irish communists, but also accentuated the problems between them. The $\mathrm{ECCl}$ expected the CPGB to exercise a fostering role over the CPI. The negative implications of such a relationship had been spelled out 50 years earlier by Engels. All too often, the CPGB acted with a paternalistic arrogance. There is no doubt that the Irish communists were weak and ineffective, but when it came to analysis of the political situation in Ireland, they were streets ahead of their British counterparts. The fact that the CPGB had to step into line with the CPI analysis of the Treaty is perhaps the best example of this. The British communists seemed unable to analyse the class basis of Irish republicanism, or the relationship between Irish republicanism and socialism, in any consistent, coherent fashion. But despite this, the CPGB continued in its attempts to dictate Irish policy. In 1923, this would reach the heights of instructing the Irish communists -12 of whom were either in prison or had been imprisoned-- the degree to which they should be involved in a republican struggle that had been all but destroyed by the Free State. 
How then should the efforts of British socialists be considered? There is no doubt that the centuries-long tradition of support for Irish freedom by British radicals was further enhanced and developed by British socialists during the Irish Revolution. Moreover, this tradition was transformed into a wider appreciation of the need to oppose imperialism more generally. This particular tradition has informed and contextualised some aspects of British socialist activity in the decades that have passed, not simply in relation to Ireland, but further afield. It was perhaps most recently in evidence in the 2-million strong march against the invasion of Iraq in 2003. But to return to Connolly's comment. After 1916, British socialists did develop a greater understanding of the republican struggle in Ireland. They certainly had more awareness of its importance. They knew it could not be ignored and needed to be supported. But for many, it still remained an issue of secondary importance. It was all too often a struggle not seen as vital to, or even connected to, their own, more important in their eyes, struggle for revolutionary change in Britain. 